\title{
RESUME MATA KULIAH HUKUM TATA NEGARA
}

\author{
NAMA = WARHAM SALIM \\ NIM $=10200120181$ \\ KELAS $=H T N-E$
}

\section{HUKUM TATA NEGARA}

\section{A.Pengertian dan Istilah Hukum Tata Negara}

pada dasarnya hukum tat Negara adalah hukum yang mengatur organisasi kekuasaan suatu negara beserta segala aspek yang berkaitan dengan organisasi negara tersebut. Sehubungan dengan itu dalam lingkungan Hukum Ketatanegaraan dikenal berbagai istilah yaitu:

1.State Law dimana yang diutamakan adalah Hukum Negara

2.State Recht ( Belanda) dimana State Recht

3.Constitutional Law (Inggris) dimana hukum tata negara lebih menitik beratkan pada konstitusi atau hukum konstitusi.

4.Droit Constitutional dan Droit Adminitrative (Perancis), dimana titik tolaknya adalah untuk membedakan antara Hukum Tata Negara dengan Hukum Aministrasi Negara.

5.Verfassnugrecht dan Vervaltingrecht ( Jerman ) yang sama dengan di Perancis.

6.Bagi Indonesia tentunya mempunyai hubungan dengan Hukum Tata Negara Belanda dengan istilah State Recht atau Hukum Negara/ Hukum Tata Negara.

\section{B. Definisi Hukum Tata Negara}

Berikut menurut beberapa pendapat para ahli tentang definisi hukum tata negara adalah yaitu :

1.Apeldoorn : Hukum Negara dalam arti sempit menunjukkan organisasi-organisasi yang memegang kekuasaan pemerintahan dan batas-batas kekuasaannya., Hukum Negara dalama arti luas meliputi Hukum Tata Negara dan Hukum Administrasi Negara.

2.Wade and Philips : Hukum Tata Negara mengatur alat-alat perlengkapan Negara, tugas, dan hubungannya antar perlengkapan Negara itu.

3.Paton : Hukum Tata Negara adalah hukum mengenai alat-alat, tugas dan wewenang alat-alat perlengkapan Negara.

4. R. Kranenburg : Hukum Tata Negara meliputi hukum mengenai susunan hukum dari Negaraterdapat dalam UUD.

5.Utrecht : Hukum Tata Negara mempelajari kewajiban sosial dan kekuasaan pejabat-pejabat Negara.

\section{Hubungan Hukum Tata Negara dengan IImu-IImu lainnya}

1. Hubungan Hukum Tata Negara dengan Ilmu Negara Keduanya mempunyai hubungan yang sangat dekat.

Ilmu Negara mempelajari :

- Negara dalam pengertian abstrak artinya tidak terikat waktu dan tempat.

- Ilmu Negara mempelajari konsep-konsep dan teori-teori mengenai Negara serta hakekat negara, Sedangkan 
Hukum Tata Negara mempelajari :

- Negara dalam keadaan konkrit artinya Negara yang sudah terikat waktu dan tempat.

- Hukum Tata Negara mempelajari Hukum Positif yang berlaku dalam suatu Negara.

- Hukum Tata Negara mempelajari Negara dari segi struktur.

Dengan demikian hubungan antara Ilmu Negara dengan Hukum Tata Negara adalah Ilmu Negara adalah dasar dalam penyelenggaraan praktek ketatanegaraan yang diatur dalam Hukum Tata Negara lebih lanjut dengan kata lain Ilmu Negara yang mempelajari konsep, teori tentang Negara merupakan dasar dalam mempelajari Hukum Tata Negara.

2.Hubungan Hukum Tata Negara dengan Ilmu Politik.

- Hukum Tata Negara mempelajari peraturan-peraturan hukum yang mengatur organisasi kekuasaan Negara, sedangkan

- Ilmu Politik mempelajari kekuasaan dilihat dari aspek perilaku kekuasaan tersebut.

Dengan kata lain Ilmu Politik melahirkan manusia-manusia Hukum Tata Negara sebaliknya Hukum Tata Negara merumuskan dasar dari perilaku politik/kekuasaan.

Menurut Barrents, Hukum Tata Negara ibarat sebagai kerangka manusia, sedangkan Ilmu Politik diibaratkan sebagai daging yang membalut kerangka tersebut.

3. Hubungan Hukum Tata Negara dengan Hukum Administrasi Negara

Hubungan Administrasi Negara. Hukum Administrasi Negara merupakan bagian dari Hukum Tata Negara dalam arti luas, sedangkan dalam arti sempit Hukum Administrasi Negara adalah sisanya setelah dikurangi oleh Hukum Tata Negara.

\section{Ruang Lingkup Hukum Tata Negara}

1. Struktur Umum dari Negara sebagai organisasi adalah :

1.Bentuk Negara ( Kesatuan atau Federasi ).

2.Bentuk Pemerintahan ( Kerajaan atau Republik )

3.Sistem Pemerintahan (Presidentil, Parlementer, Monarki absolute)

4.Corak Pemerintahan ( Diktator Praktis, Nasionalis, Liberal, Demokrasi)

5.Sistem Pendelegasian Kekuasaan Negara ( Desentralisasi, meliputi jumlah, dasar, cara dan hubungan antara pusat dan daerah) dll.

2. Badan-badan Ketatanegaraan yang mempunyai kedudukan dalam organisasi Negara ( MPR, DPR, DPD, Presiden, BPK, MA,MK,KY) yaitu menyangkut masalah:

1.Cara pembentukannya ( Pengangkatan, Pemilihan)

2.Susunan masing-masing badan ( Jumlahjenis anggota dan pembagian tugas )

3.Tugas dan wewenang masing-masing badan

4.Cara kerjanya masing-masing badan.

5.Perhubungan kekuasaan antara badan

6.Masa Jabatan

7.Badan-badan lain

3. Pengaturan Kehidupan Politik Rakyat

1.Jenis, penggolongan dan jumlah partai politik didalam Negara dan ketentuan hukum yang mengaturnya.

2.Hubungan antara kekuatan-kekuatan politik dengan badan-badan ketatanegaraan.

3.Kekuatan politik dan pemilihan umum

4.Arti dan kedudukan golongan kepentingan. DII 


\section{SUMBER SUMBER HUKUM TATA NEGARA}

\section{A.Pengertian Sumber Hukum}

Dalam bahasa Inggris, sumber hukum itu disebut source of law. Perkataan sumber hukum itu sebenarnya berbeda dari perkataan dasar hukum, landasan hukum, ataupun payung hukum. Dasar hukum ataupun landasan hukum adalah legal basis atau legal ground, yaitu norma hukum yang mendasari suatu tindakan atau perbuatan hukum tertentu sehingga dapat dianggap sah atau dapat dibenarkan secara hukum. Sedangkan, perkataan sumber hukum lebih menunjuk kepada pengertian tempat dari mana asal-muasal suatu nilai atau norma tertentu berasal. Dalam Pasal 1 Ketetapan MPR No. III/MPR/ 2000 ditentukan bahwa: (1) Sumber hukum adalah sumber yang dijadikan bahan untuk penyusunan peraturan perundang-undangan.

\section{B. Definisi sumber hukum}

Berikut beberapa pendapat tentang sumber hukum yaitu :

1.Hans Kelsen dalam bukunya "General Theory of Law and State", istilah sumber hukum itu (sources of law) dapat mengandung banyak pengertian, karena sifatnya yang figurative. sources of law juga dapat dikaitkan dengan cara untuk menilai alasan atau the reason for the validity of law. Semua norma yang lebih tinggi merupakan sumber hukum bagi norma hukum yang lebih rendah. Oleh karena itu, pengertian sumber hukum (sources of law) itu identik dengan hukum itu sendiri (the source of law is always itself law).

2. R. Suroso dalam bukunya, Sumber Hukum adalah segala sesuatu yang menimbulkan aturan-aturan yang mengikat dan memaksa, sehingga apabila aturan-aturan itu dilanggar akan menimbulkan sanksi yang tegas dan nyata bagi pelanggarnya.

3.Pengertian Sumber Hukum menurut Sudikno Mertokusumo yaitu :

- sumber hukum Sebagai asas hukum, sebagai sesuatu yang merupakan permulaan hukum, misalnya kehendak Tuhan, akal manusia, jiwa bangsa, dan sebagainya.

- Menunjukkan hukum terdahulu yang memberi bahan-bahan pada hukum yang sekarang berlaku seperti hukum Perancis, hukum Romawi, dan lain-lain.

- Sebagai sumber Hukum berlakunya, yang memberi kekuatan berlaku secara formal kepada peraturan hukum (penguasa atau masyarakat).

- Sebagai sumber terjadinya hukum atau sumber yang menimbulkan hukum.

- Sebagai sumber darimana kita dapat mengenal hukum, misalnya dokumen, undang-undang, lontar, batu tertulis dan sebagainya

\section{Macam-Macam Sumber Hukum}

sumber hukum dibagi menjadi dua yaitu sumber hukum formil dan sumber hukum materil.

1.Sumber hukum formil

Sumber hukum formil merupakan tempat atau sumber dari mana suatu peraturan memperoleh kekuatan hukum. Ini berkaitan dengan bentuk atau cara yang menyebabkan peraturan hukum itu berlaku secara formal yakni :

a. Undang-Undang

b. Traktat

c. Konvensi

Tatanan kebiasaan merupakan tatanan yang norma-normanya sangat dekat dengan kenyataan kehidupan sehari-hari. Hal ini disebabkan karena kebutuhan masyarakat yang begitu rumit, kompleks dan selalu berubah-ubah, sedangkan undang-undang yang berlaku secara positif dan telah terkodifikasi belum tentu dapat memenuhi kebutuhan hukum dalam kehidupan masyarakat, sehingga terbentuklah suatu tatanan yang disepakati berlaku terhadap anggota masyarakat. Apa 
yang biasa dilakukan oleh orang-orang, itulah yang kemudian dapat menjelma menjadi norma kebiasaan.

d. Doktrin

Doktrina berasal dari kata doctor, yang dalam bahasa latin berarti : Guru, Doctrina berarti apa yang telah diajarkan guru atas dasar ilmu. Dari asal kata doktrina itu, dapatlah kita ambil pengertian bahwa yang dimaksud dengan doktrina adalah hukum yang diciptakan oleh orang-orang cerdik pandai. Atau dengan pengertian lain doktrina adalah pendapat-pendapat dari ahli hukum tentang suatu hal yang mengenai hukum.

e. Yurisprudensi (keputusan hakim )

Yurisprudensi adalah proses penemuan hukum yang dilakukan oleh hakim berdsarkan kasus kasus kongkrit yang terjadi dalam masyarakat yang kemudian menjadi preseden bagi kepuutusan keputusan hakim selanjutnya. Sedangkan

\section{Sumber hukum materil}

Sumber hukum materil merupakan faktor yang membantu pembentukan hukum misalnya hubungan sosial, hubungan kekuatan politik, situasi sosial ekonomi, tradisi (kriminologi, lalu-lintas), perkembangan internasional, keadaan geografis.

\section{Sumber Hukum Tata Negara}

Sumber hukum tata Negara Indonesia dengan pengertian jenis atau bentuk. Dari pandangan ini, sumber Hukum Tata Negara Indonesia antara lain :

1. Undang-Undang Dasar 1945

UUD 1945 sebagai sumber hukum, yang merupakan hukum dasar tertulis yang mengatur masalah kenegaraan dan merupakan dasar ketentuan-ketentuan lainnya. Bentuk bentuk peraturan perundang undangan Republik Indonesia menurut UUD 45 adalah : undang undang dasar, ketetapan MPR, undang undang dan atau peraturan pemerintah pengganti undang undang (perpu), peraturan pemerintah, keputusan presiden, peraturan pelaksanaan lainnya, seperti peratuatn menteri, intruksi menteri dan peraturan daerah.

2.Ketetapan MPR

Dalam Pasal 3 UUD 1945 ditentukan bahwa Majelis Permusyawaratan Rakyat menetapkan UndangUndang Dasar dan Garis-Garis Besar Haluan Negara. Dengan istilah menetapkan tersebut maka orang berkesimpulan, bahwa produk hukum yang dibentuk oleh MPR disebut Ketetapan MPR. Ketetapan MPR meliputi : ketetapan MPR yang menurut garis garis besar dalam bidang legislative dilaksanakan dengan undang undang dan ketetapan MPR yang memeuat garis garis besar dalam bidang ekskutif dilaksanakan dengan keputusan daerah.

3.Peraturan pemerintah pengganti undang-undang

Dalam hal keadaan dan kepentigan yang memaksa, presiden berhak menetapkan peraturan peraturan pemerintah sebagai pengganti undang undang (perpu). Peraturan pemerintah harus mendapat persetujuan dewan perwakilan rakyat dalam persidangan, namun jika tidak mendapat persetujuan, peraturan pemerintah itu harus dicabut.

4.Peraturan Pemerintah

Untuk melaksanakan undang-undang yang dibentuk oleh Presiden dengan DPR, oleh UUD 1945 kepada presiden diberikan kewenangan untuk menetapkan Peraturan Pemerintah guna melaksanakan undang-undang sebagaimana mestinya. Dalam hal ini berarti tidak mungkin bagi presiden menetapkan Peraturan Pemerintah sebelum ada undang-undangnya, sebaliknya suatu undang-undang tidak berlaku efektif tanpa adanya Peraturan Pemerintah.

5.Keputusan Presiden

UUD 1945 menentukan Keputusan Presiden sebagai salah satu bentuk peraturan perundangundangan. Bentuk peraturan ini baru dikenal tahun 1959 berdasarkan surat presiden no. 2262/HK/1959 yang ditujukan pada DPR, yakni sebagai peraturan perundang-undangan yang dibentuk oleh presiden untuk melaksanakan Penetapan Presiden. Kemudian melalui Ketetapan 
MPRS No. XX/MPRS/1966, Keputusan Presiden resmi ditetapkan sebagai salah satu bentuk peraturan perundang-undangan menurut UUD 1945. Keputusan Presiden berisi keputusan yang bersifat khusus (einmalig) adalah untuk melaksanakan UUD 1945, Ketetapan MPR yang memuat garis-garis besar dalam bidang eksekutif dan Peraturan Pemerintah.

6. Peraturan pelaksana lainnya

Yang dimaksud dengan peraturan pelaksana lainnya adalah seperti Peraturan Menteri, Instruksi Menteri dan lain-lainnya yang harus dengan tegas berdasarkan dan bersumber pada peraturan perundang-undangan yang lebih tinggi.

7.Convention (Konvensi Ketatanegaraan)

Konvensi Ketatanegaraan adalah perbuatan kehidupan ketatanegaraan yang dilakukan berulangulang sehingga ia diterima dan ditaati dalam praktek ketatanegaraan. Konvensi Ketatanegaraan mempunyai kekuatan hukum yang sama dengan undang-undang, karena diterima dan dijalankan, bahkan sering kebiasaan (konvensi) ketatanegaraan menggeser peraturan-peraturan hukum yang tertulis.

8.Traktat

Traktat atau perjanjian yaitu perjanjian yang diadakan dua negara atau lebih. Kalau kita amati praktek perjanjian internasional bebrapa negara ada yang dilakukan 3 (tiga) tahapan, yakni perundingan (negotiation), penandatanganan (signature), dan pengesahan (ratification). Disamping itu ada pula yang dilakukan hanya dua tahapan, yakni perundingan (negotiation) dan penandatanganan (signature).

\section{ASAS ASAS HUKUM TATA NEGARA}

\section{Pengertian Asas Hukum}

Asas adalah pandangan untuk mengatur suatu rangkaian tertentu terhadap suatu hal (atau dapat juga disebut sebagai grean desaing terhadap suatu hal tertentu) Asas bukan merupakan norma yang harus ditaati tetapi dapat diikuti atau dipedomi. Asas-asas dalam Hukum Tata Negara dapat dilihat dalam Undang-Undang Dasar yang merupakan hukumpositif dan mengatur mengenai asas-asas dan pengertian-pengertian dalam penyelenggaraan Negara

\section{Asas Hukum Tata Negara}

\section{A. Asas Pancasila}

Asas pancasila adalah sumber hukum materil karena itu setiap pengaturan isi peraturan perundangan tidak boleh bertentangan pada Pancasila dan bila terjadi maka peraturan tersebut harus segera dicabut.

Pancasila sebagai asas Hukum Tata Negara bisa dilihat dari:

- Asas Ketuhanan Yang Maha esa (sila ke-1)

- Asas Prikemanusiaan (Sila Ke-2).

- Asas Kebangsaan (Sila Ke-3)

- Asas Kedaulatan Rakyat (Sila Ke-4)

- Asas keadilan (Sila Ke-5)

\section{B. Asas Kedaulatan Rakyat}

Dalam Hukum Tata Negara pengertian kedaulatan bisa relatif, maksudnya bahwa kedaulatan itu tidak hanya dikenal pada negara-negara yang memiliki kekuasaan penuh keluar dan kedalam tapi juga dapat dikenakan kepada negara-negara yang berhubungan pada sebuah perjanjian yang berbentuk traktat atau dalam bentuk konfederasi atau federasi.kedaulatan tersebut tidak terpecahpecah karena dalam suatu negara hanya ada satu kekuassan yang teringgi. 
Kedaulatan rakyat adalah bahwa rakyatlah yang memiliki wewenang yang tertinggi yang menentukan segala wewenang dalam negara kedaulatan rakyat diwakilkan pada MPR, kekuasaan majelis itu nyata dan ditentukan oleh UUD tapi oleh karena majelis merupakan sebuah badan yang besar dan lamban sifatnya maka ia menyerahkan lagi kepada badan-badan yang ada dibawahnya.

\section{Asas Negara Hukum}

Yang dimaksud dengan Negara Hukum adalah Negara yang berdiri di atas hukum yang menjamin keadilan pada warga Negaranya. Keadilan adalah syarat bagi tercapainya kebahagiaan hidup untuk warga negaranya, dan sebagai dasar dari pada keadilan perlu di ajarkan rasa susila pada setiap manusia supaya dia menjadi warga Negara yang baik. Demikian pula peraturan hukum yang sebenarnya hanya ada bila peraturan hukum itu mencerminkan keadilan bagi pergaulan hidup antar warga negaranya.

\section{Asas Pembagian Kekuasaan}

Pengertian pembagian kekuasaan beda dari pengertian pemisahan kekuasaan. Pemisahan kekuasaan artinya bahwa kekuasaan Negara itu terpisah-pisah dalam beberapa bagian, baik mengenai orangnya ataupun fungsinya. Kenyataan menunujukan bahwa sebuah pemisahan kekuasaan murni tidak bisa dilaksanakan. Karena itu pilihan jatuh kepada istilah pembagian kekuasaan yang artinya bahwa kekuasaan itu dibagi-bagi dalam beberapa bagian, namun tidak dipisahkan. Hal membawa konsekuensi bahwa di antara bagian-bagian tersebut dimungkinkan adanya kerjasama.

\section{E. Asas Negara Kesatuan}

Pada dasarnya Negara kesatuan dideklarasikan pada saat menyatakan/memproklamirkan kemerdekaan oleh para pendiri Negara dengan menyatakan seluruh wilayah sebagai bagian dari satu Negara. Salah satu cara untuk menjaga keutuhan negara ini yakni dengan membentuk hukum tata negara yang bisa menjaga persatuan dan kesatuan bangsa ini. Terkandung dalam UUD 1945, pasal 1 ayat (1) sudah ditegaskan bahwa Indonesia merupakan suatu negara kesatuan yang berbentuk republik. Setiap hukum tata negara yang hendak dibentuk harus memperhatikan pada hal ini. Tidak dibenarkan adanya materi di dalam hukum tata negara yang mempunyai peluang untuk memecah belah bangsa ini. Oleh sebab itu, salah satu tahapan kebijakan publik adalah menguji kebijakan publik, semata untuk mencegah supaya kebijakan publik tersebut berpotensi menjadi penyebab konflik sosial.

\section{SEJARAH KETATANEGARAAN INDONESIA}

\section{A.Perubahan Sistem Pemerintahan Negara}

Pelaksanaan pemerintahan Negara di bawah UUDS tentunya berbeda pada pemerintahan sebelumnya yaitu dengan segara dibentuk alat-alat perlengkapannya. Presiden RIS yaitu Presiden Soekarno, menurut Piagam Persetujuan Pemerintahan negara RIS dan pemerintah negara RI pasal 3 sub e adalah tetap sebagai presiden negara kesatuan. Sedangkan kabinet pertama dalam negara kesatuan ini, ialah kabinet Natsir, yaitu kabinet yang ada pada waktu itu. Tetapi kemudian diganti dengan kabinet Sukiman pada tanggal 6 September 1950. Untuk dapat melakukan tugas DPR sebelum dapat dibentuk DPR dalam pasal 56 dan pasal 57, maka untuk sementara maksud dibentuk dewan perwakilan rakyat sementara (DPRS) yang anggotanya terdiri dari:

1. gabungan dewan perwakilan rakyat sementara republik Indonesia serikat, ketua, wakil ketua dan anggota-angggotanya,

2. senat, ketua, wakil-wakil ketua, 
3.dan anggota-angggota badan pekerja KNIP dan ketua, wakil ketua dan anggota-anggota dewan pertimbamngan agung - pasal 77.

Setelah Proklamasi Kemerdekaan RI pada tanggal 17 Agustus 1945, Indonesia mengesahkan Konstitusi pada 18 Agustus 1945 oleh PPKI dalam sebuah naskah yang dinamakan UUD Negara RI, yang memuat hal-hal yang pokok saja sedangkan didalam melaksanakan aturan yang pokok tersebut diserahkan kepada Undang-Undang yang lebih rendah. Menurut UUD 1945, sistem pemerintahan Indonesia adalah presidensil, dalam arti kepala Pemerintahan Republik Indonesia dipimpin oleh Presiden dan dibantu oleh seorang Wakil Presiden \{pasal 4 ayat (1) dan ayat (2)\}.

Dalam hal yang terpenting menurut Joeniarto, di Indonesia telah terjadi konstelasi ketatanegaraan. Jika semula UUD menganut sistem presidensil dengan maklumat tersebut prinsip pertanggung jawaban menteri dengan resmi diakui. Terjadi pergeseran kekuasaan eksekutif yang semula menteri bertanggungjawab kepada presiden sekarang terhadap perdana menteri. Dengan dikeluarkannya maklumat pemerintah tersebut bergeserlah kekuasaan presiden dan mengubah sistem ketatanegaraan yang tadinya presidensil menjadi parlementer.

\section{B. Perkembangan Konstitusi di Indonesia}

Dalam sejarah ketatanegaraan Indonesia ada empat macam Undang-Undang yang pernah berlaku, yaitu :

1. UUD 1945 (berlaku antar 17 Agustus 1945-27 Desember 1939),

2.Konstitusi Republik Indonesia Serikat (berlaku 27 Desember 1949-17 Agustus 1950),

3. UUDS 1950 (berlaku pada 17 Agustus 1950-5 Juli 1959), dan

4. UUD 1945 (berlaku setelah adanya Dekrit Presiden 5 Juli).

Dalam keempat periode tersebut, UUD 1945 berlaku selama dua kali. Pertama diundangkan dalan Berita Republik Indonesia Tahun II No. 7. Kedua, melalui dekrit Presiden 5 Juli 1945. Perkembangan ketatanegaraan Indonesia sejak Proklamasi dengan UUD dan Pancasila sebagai Falsafah Negara tidak berjalan dengan mulus karena Belanda selalu ingin menancapkan kembali kekuasaannya. Pada tanggal 2 November 1949 diadakan Konferensi Meja Bundar kemudian dilakukan pengesahan pda tanggal 27 Desember 1949 tentang penyerahan kedaulatan terhadap Indonesia. Naskah Konstitusi RIS disusun bersama oleh delegasi RI dan delegasi bijeenkomst voor federal overleg (BFO) ke KMB dan disepakati kedua belah pihak untuk diberlakukan dan di Indonesia dikenal dengan Konstitusi RIS. Disampaikan kepada KNIP dan mendapat persetujuan pada tanggal 14 Desember 1949 kemudian dinyatakan berlaku pada 27 Desember 1949.

Dalam rangka terbentuknya kembali negara kesatuan maka perlu menyiapkan naskah UUD dan dibentuklah panitia yang akan menyusun rancangannya. Setelah selesai UUD tersebut disahkan oleh KNIP tanggal 12 Agustus 1950 dan oleh DPR dan Senat Republik Indonesia Serikat tanggal 14 Agustus 1950 dan mulai diberlakukan pada tanggal 17 Agustus 1950, yaitu dengan ditetapkannya UU No. 7 Tahun 1950. UUDS bersifat sementara sehingga isinya tidak mencerminkan perubahan terhadap Konstitusi RIS 1949. Tetapi menggantikan naskah Konstitusi RIS dengan nama Undang-Undang Dasar Sementar 1950.

\section{Dekrit Presiden 5 Juli 1959}

Seperti halnya Konstitusi RIS 1949, UUDS 1950 ini juga bersifat sementara yang terlihat dalam rumusan Pasal 134, yang mengharuskan Konstituante bersama-sama dengan pemerintah segera menyusun UUD RI yang akan menggantikan UUDS 1950 itu. Tapi, berbeda dari konstitusi RIS yang tidak sempat membentuk Konstituante sebagai mana diamanatkan didalamnya, amanat UUDS 1950 telah dilaksanakan sehingga pemilihan umum berhasil diselenggarakan pada bulan Desember 1955 untuk memilih anggota Konstituante. Pemilihan Umum ini diadakan berdasarkan ketentuan UU No.7 tahun 1953. Undang-undang ini berisi dua pasal. Pertama, berisi ketentuan perubahan Konstitusi RIS 
menjadi UUDS 1950. Kedua, berisi ketentuan mengenai tanggal mulai berlakunya UUDS tahun 1950 itu menggantikan Konstitusi RIS, yaitu tanggal 17 Agustus 1950. Atas dasar UU inilah diadakan pemilu tahun 1955, yang menghasilkan terbentuknya Konstituante yang diresmikan di Bandung pada 10 November 1956.

Akibat dari Majelis Konstituante yang belum berhasil, Presiden Soekarno berkesimpulan Konstituante telah gagal. la mengeluarkan Dekrit tanggal 5 juli 1959 sebagai UUD Negara Republik Indonesia selanjutnya. Tindak mengeluarkan Dekrit 5 Juli 1959 menjadi kontroversi keputusan Presiden No. 150 Tahun 1959, dan isi dekrit yang memberlakukan membubarkan konstituante. Sejak dikeluarkan Dekrit 5 Juli 1959 sampai sekarang, UUD 1945 terus berlaku dan diberlakukan sebagai hukum dasar. Dekrit tersebut dikeluarkan dengan alasan bahwa anjuran Presiden dan pemerintah untuk kembali kepada UUD 1945, yang disampaikan kepada segenap Rakyat Indonesia dengan Amanat Presiden pada 22 April 1959, tidak memperoleh keputusan dari Konstituante sebagaimana ditentukan dalam UUD.

\section{Reformasi dan Perubahan UUD 1945}

Salah satu berkah Reformasi ialah perubahan UUD 1945. Dari Orde Lama dengan Demokrasi Terpimpin dan pengangkatan sebagai Presiden seumur hidup dengan ketetapan MPR merupakan salah satu penyelewengan UUD 1945 dan Orde Baru hanya melahirkan sistem diktator dalam kepemimpinan sebuah negara. Sejak terjadi Reformasi UUD menjadi "desakralisasi", alasan perubahan UUD 1945 secara filosofis, pertama, karena UUD 1945 adalah moment opname dari brbagai kekuatan politik dan ekonomi yang dominant pada saat dirumuskannya konstitusi itu. Kedua, UUD 1945 disusun oleh manusia yang sesuai kodratnya tidak akan pernah sampai kepada tingkat kesempurnaan.

Sedangkan dari aspek historis, dari mulai pembuatannya UUD 1945 bersifat sementara, sebagaimana yang dinyatakan oleh Ir. Soekarno (Ketua PPKI), dalam rapat pertama 18 Agustus 1945. Secara yuridis, para perumus UUD 1945 sudah menunjukan kearifan bahwa yang mereka lakukan ketika UUD 1945 disusun tentu akan berbeda kondisinya dimasa yang akan datang dan mungkin suatu saat akan mengalami perubahan. Baik dilihat dari sejarah penyusunan maupun sebagai produk hukum yang mencerminkan pikiran dan kepentingan yang ada pada saat itu. Tidak ada ketentuan lain menyangkut perubahan UUD 1945 sebab tambahan muncul kemudian, yaitu melalui interpretasi histories dan filosofis oleh ketetapan MPR No. XX/MPRS/1966, bahwa Pembukaan UUD 1945 dinyatakan tidak dapat dirubah.

Dorongan memperbarui atau mengubah UUD 1945 didasarkan pula pada kenyataan bahwa UUD 1945 sebagai subsistem tatanan konstitusi dalam pelaksanaannya tidak berjalan sesuai dengan staatsidee mewujudkan Negara berdasarkan konstitusi. Secara substansip, UUD 1945 banyak sekali kelemahan. Hal itu dapat diketahui antara lain pertama kekuasaan eksekutif terlalu besar tanpa disertai oleh prinsip checks and balances yang memadai. Kedua, rumusan ketentuan UUD 1945 sebagian besar bersifat sangat sederhana, umum, bahkan tidak jelas (vague) sehingga banyak pasal yang menimbulkan multi tafsir. Ketiga, unsur-unsur konstitusionalisme tidak dielaborasi secara memadai dalam UUD 1945. Keempat, UUD 1945 terlalu menekan kepada semangat penyelenggara negara. Kelima, UUD 1945 memberikan atribusi kewenangan yang terlalu besar kepada Presiden unuk mengatur berbagai hal penting dalam UU. Keenam, banyak materi muatan yang penting justru diatur didalam Penjelasan UUD, tetapi tidak tercantum didalam pasal-pasal UUD 1945. Ketujuh, status dan materi Penjelasan UUD 1945.

Fraksi-fraksi di MPR menyepakati bahwa perubahan UUD 1945 tidak mengganggu eksistensi negara, tetapi dimaksudkan untuk memperbaiki dan menyempurnakan penyelenggaraan Negara agar lebih demokratis, seperti disempurnakannya sistem checks and balances dan disempurnakannya pasalpasal mengenai hak asasi manusia. 


\section{KONSTITUSI SEBAGAI OBJEK KAJIAN HUKUM TATA NEGARA}

\section{A.Pengertian dan istilah konstitusi}

Istilah konstitusi berasal dari bahasa Perancis (constituer) yang berarti membentuk. Pemakaian istilah konstitusi yang dimaksudkan ialah pembentukan suatu negara atau menyusun dan menyatakan suatu negara.

1. Sehingga konstitusi mengandung permulaan dari segala peraturan mengenai suatu negara, dengan demikian suatu konstitusi memuat suatu peraturan pokok (fundamental) mengenai sendisendi pertama untuk menegakkan bangunan besar yaitu negara.

2. Bertolak dari konsepsi tersebut, maka secara umum istilah konsitusi menggambarkan keseluruhan sistem ketatanegaraan suatu negara, yaitu berupa kumpulan peraturan yang membentuk, mengatur, atau memerintah negara. Peraturan-peraturan tersebut ada yang tertulis dan yang tidak tertulis. 3.Pengertian konstitusi, dalam prakteknya dapat berarti lebih luas daripada pengertian UndangUndang Dasar, tetapi ada juga yang menyamakan dengan pengertian Undang-Undang Dasar.

\section{B.Definisi Konstitusi}

Berikut beberapa pandangan para ahli tentang definisi konstitusi yaitu :

1.L.J. Van Apeldoorn telah membedakan secara jelas di antara keduanya, kalau gronwet (Undangundang Dasar) adalah bagian tertulis dari suatu konstitusi, sedangkan constitution (konstitusi) memuat baik peraturan tertulis maupun yang tidak tertulis.

2. Sri Soemantri M, dalam disertasinya mengartikan konstitusi sama dengan Undang-undang Dasar. Penyamaan arti dari keduanya ini sesuai dengan praktek ketatanegaraan di sebagian besar negaranegara di dunia termasuk di Indonesia.

3.Herman Heller membagi pengertian konstitusi menjadi 3 yaitu :

-Die Politische verfassung als gesellschaftlich wirklichkeit. Konstitusi adalah mencerminkan kehidupan politik di dalam masyarakat sebagai kenyataan. Jadi mengandung pengertian politis dan sosiologis.

-Die Verselbstandigte rechtsverfassung. Konstitusi merupakan suatu kesatuan kaidah yang hidup dalam masyarakat. Jadi mengandung pengertian yuridis.

-Die geshereiben verfassung. Konstitusi yang ditulis dalam suatu naskah sebagai undang-undang yang tertinggi yang berlaku dalam suatu negara.

\section{Pembagian dan Klasifikasi Konstitusi}

Carl Schmitt dan K.C wheare dalam bukunya Verfassungslehre, membagi konstitusi dalam empat bagian yaitu :

1.Konstitusi absolut (absolut begriff der verfassung)

2.Konstitusi relatif (relative begriff der verfassung)

3.Konstitusi positif (positive begriff der verfassung)

4.Konstitusi ideal (ideal begriff der verfassung)

1.Konstitusi Absolut

- Konstitusi sebagai kesatuan organisasi. Dalam hal ini Kesatuan Organisasi ini menjangkau semua perangkat hukum yang ada kaitannya dengan kenegaraan serta semua organisasi yang ada dalam negara.

- Konstitusi sebagai pembentuk negara. Bahwa dengan diberlakukannya konstitusi, dapat segera ditunjukkan kelengkapan bentuk dari negara tersebut, apakah bentuknya itu demokrasi ataukah monarki. Mengenai sendi demokrasi itu (secara langsung atau tidak langsung) telah mengemukakan suatu identitas bahwa dalam hal ini kepentingan konstitusi tertuju kepada rakyat, perjuangannya jalan pencapai tujuannya guna mebncapai tujuan/cita-cita dengan penuh keberhasilan. Sedangkan sendi yang berkaitan dengan monarki menunjukkan suatu representasi, yaitu adanya raja sebagai 
kepala negara yang berlaku secra turun temurun sebagai suatu lambang dari bentuk negara, tetapi dalam hal kekuasaannya tetap, pada dasarnya berada pada rakyat.

- Konstitusi sebagai faktor pengimbang pelancar (integrasi). Demi kepentingan hubungan dalam percaturan hidup di dunia sangat diperlukan lambang dari ciri-ciri yang menunjukkan adanya negara yang teratur. Lambang dan ciri-ciri ini akan memperlancar, lebih memantapkan dan lebih menjamin keteraturannya itu, seperti: adanya lagu kebangsaan, bahasa nasional, bendera, dan lambang kenegaraan. Selain itu (dalam hal integrasi yang bersifat abstrak), konstitusi dapat menciptakan integrasi yang bersifat fungsional seperti halnya memantapkan persatuan dan perkembangan bangsa dengan jaminan pemilihan umum, referendum, pembentukan parlemen, kabinet, dan lain sebagainya.

- Konstitusi sebagai norma-norma hukum tertinggi yang menjadi dasar dari segala-galanya, atau menjadi sumber bagi segala peraturan hidup yang diberlakukan dalam negara tersebut.

\section{Konstitusi Relatif}

Dalam hal pengertian konstitusi yang relatif ini penjelasan yang dikemukakan adalah sekitar konstitusi dalam arti formal atau yang tertulis. Konstitusi formal dapat diberlakukan untuk jangka waktu panjang, sampai puluhan atau ratusan tahun, tergantung dari arti materiilnya atau isinya. Jadi kalau segi materiilnya memang fleksibel, mantap bagi kehidupan dan perkembangan negara dan bangsa, tentulah konstitusi demikian akan dipertahankan. Jaminan dari segi materiil ini adalah tergantung dari segi perancanagan, pembuatan atau prosedur-prosedur dalam penciptaan atau penyusunannya. Tentunya prosedur yang paling baik ialah yang melibatkan banyak pihak, yang lazimnya dapat menunjukkan demokrasi. Isi dari kesepakatan dalam penyusunan selanjutnya diwujudkan sebagai konstitusi atau Undang-Undang Dasar yang tertulis. Segi relatifnya terletak pada perubahan-perubahan, penambahan, perbaikan, yaitu jika dipandang perlu sehubungan dengan diperolehnya perbaikan yang memantapkan konstitusi tersebut.

\section{Konstitusi Positif}

Konstitusi dalam arti positif mengandung pengertian sebagai keputusan politik tertinggi, yang menentukan nasib seluruh rakyat dimana konstitusi itu diberlakukan. Adapun keputusan politik tertingi lazimnya menunjukkan perubahan-perubahan yang menuju perbaikan, atau perkembangan negara dan bangsa, misalnya memberikan garis-garis besar bagi pengaturan kehidupan bangsa dan negara setelah perolehan kemerdekaan, perebutan kemerdekaan, dan lain sebagainya. Garis-garis besar peraturan ini mutlak harus dijalankan dan ditaati sebagai hal-hal yang teruji kepositifannya.

\section{Konstitusi Ideal}

Jika melihat dari segi demokrasi atau kepentingan rakyat, maka konstitusi yang ideal dengan sendirinya yang dapat memberikan jaminan perlindungan terhadap hak-hak asasi, cita-cita yang timbul lainnya dengan melalui konstitusi agar pemerasan, perbuatan sewenang-wenang terhadap rakyat dapat dihilangkan, dan sebagi gantinya rakyat diberikan hak-hak kebebasan dan persamaan hak.

\section{Perubahan Konstitusi}

Secara garis besar konstitusi dapat berubah atau diubah melalui dua jalan, yakni melalui cara berikut:

1. Jalan yuridis formal.

Jalan pertama, dilakukan sesuai dengan ketentuan formal mengenai perubahan konstitusi yang terdapat di dalam konstitusi itu sendiri dan mungkin diatur dalam peraturan perundangan lain. 2. Jalan non yuridis formal atau jalan politis.

Perubahan konstitusi tersebut biasanya terjadi Karena sebab tertentu atau keadaan khusus yang mendorong terjadinya perubahan konstitusi. Perubahan demikian dapat berupa perubahan total atau sebagian ketentuan saja sesuai kebutuhan. Perubahan konstitusi secara politis ini kalau berjalan dan dapat diterima oleh segala lapisan masyarakat, maka perubahan demikian secara yuridis adalah 
sah. Atau dengan kata lain, perubahan konstitusi secara de facto yang kemudian dapat diterima oleh seluruh rakyatnya, maka konvensi statusnya berubah menjadi de jure.

Perubahan konstitusi di atas sesuai dengan George Jellinek, yang membedakan dua cara perubahan konstitusi, yaitu melalui cara berikut:

1.Yang disebut verfassungs-anderug, yakni cara perubahan konstitusi yang dilakukan dengan sengaja dengan cara yang ditentukan konstitusi.

2.Melalui prosedur yang disebut verfassung-wandelung, yakni perubahan konstitusi yang dilakukan tidak berdasarkan cara formal yang ditentukan dalam konstitusi sendiri, melainkan melalui jalur istimewa, seperti revolusi, kudeta, dan konvensi. Dan

Dua cara tersebut dapat dikembangkan lagi menjadi empat macam cara, sebagaimana yang dikemukakan oleh K.C. Wheare, yaitu sebagaimana cara berikut:

1.Perubahan konstitusi yang terjadi akibat kekuatan-kekuatan yang bersifat primer (some primary forces), seperti dorongan faktor politik.

2.Perubahan yang dilakukan sesuai dengan ketentuan dalam konstitusi (formal amandement).

3.Perubahan konstitusi melalui penafsiran hakim atau pengadilan (judicial interpretation).

4.Perubahan konstitusi oleh suatu kebiasaan dan konvensi yang lahir apabila ada kesepakatan rakyat (usage and convention).

Berdasarkan pendapat di atas dapat di simpulkan bahwasanya terdapat dua macam perubahan konstitusi, pertama perubahan secara formal yakni formal amandement, dan kedua perubahan di luar cara formal yakni some primary force, judicial interpretation, dan usage and convention.

\section{ORGAN DAN FUNGSI KEKUASAAN NEGARA}

\section{A.Pembatasan Kekuasaan}

1. Fungsi-fungsi Kekuasaan

Salah satu ciri negara hukum, adalah adanya ciri pembatasan kekuasaan dalam penyelenggaraan kekuasaan negara. Pembatasan itu dilakukan dengan hukum yang kemudian menjadi ide dasar paham konstitusionalisme modern. Ide pembatasan kekuasaan itu dianggap mutlak harus ada, karena sebelumnya semua. fungsi kekuasaan Negara terpusat dan terkonsentrasi di tangan satu orang,yaitu di tangan Raja dan Ratu ataupun pemerintah yang memimpin Negara secara turun temurun. Menurut van Vollenhoven membagi fungsi kekuasaan juga dalam empat fungsi, yang kemudian biasa disebut dengan catur praja, yaitu :

- Regeling (pengaturan) yang kurang lebih identik dengan fungsi legislatif menurut Montesquieu, -Bestuur yang identik dengan fungsi pemerintahan eksekutif,

-Rechtspraak (peradilan), dan

-Politie yang menurutnya merupakan fungsi untuk menjaga ketertiban

\section{Pembagian dan Pemisahan Kekuasaan}

persoalan pembatasan kekuasaan (limitation of power)berkaitan erat dengan teori pemisahan kekuasaan (separation of power) dan teori pembagian kekuasaan (devision of power atau distributionof power). Penggunaan istilah, division of power, separationof power, distribution of power, dan allocation of power ,memiliki nuansa yang sebanding dengan pembagian kekuasaan, pemisahan kekuasaan, pemilihan kekuasaan, dan distribusi kekuasaan. 
Istilah pemisahan kekuasaan dalam bahasa Indonesia merupakan terjemahan perkataan separation of power berdasarkan teori trias politica atau tiga fungsi kekuasaan, yang harus dibedakan dan dipisahkan secarastructural dalam organ-organ yang tidak saling mencampuri urusan masingmasing. Untuk membatasi pengertian separation of powers itu, dalam bukunya Constitutional Theory, G. Marshall membedakan ciriciri doktrin pemisahan kekuasaan (separation of powers) itu ke dalam lima aspek, yaitu :

- Differentiation;doktrin pemisahan kekuasaan(separation of powers) itu bersifat membedakan fungsi-fungsi kekuasaanlegislatif, eksekutif, dan yudisial

- Legal incompatibility of office holding; doktrin pemisahan kekuasaan Menghendaki orang yang menduduki jabatan dilembaga legislatif tidak boleh merangkap pada jabatan di luarcabang legislatif.

- Isolation, immunity, independence;doktrin pemisahankekuasaan juga menentukan bahwa masingmasing organ tidak boleh turut campur atau melakukan intervensi terhadap kegiatan organ yang lain.

- Checks and balances;dalam doktrin pemisahan kekuasaanitu, yang juga dianggap paling penting adalah adanya prinsipchecks and balances, di mana setiap cabang mengendalikan dan mengimbangi kekuatan cabang-cabang kekuasaan yang lain.

- Coordinate status and lack of accountability adalah prinsip koordinasi dan kesederajatan, yaitu semua organ ataulembaga (tinggi) Negara

Perlu diketahui bahwasanya mengenai istilah "pembagian" itu telah dipergunakan oleh Pasal 18 ayat (1) UUD 1945 untuk pengertian pembagian dalam konteks pengertian yang bersifat vertikal atau territorial division of power.

\section{Desentralisasi dan Dekonsentrasi}

Menurut Hoogerwarf, desentralisasi merupakan pengakuan atau penyerahan wewenang oleh badan-badan publik yang lebih tinggi kepada badan-badan publik yang lebih rendah kedudukannya untuk secara mandiri dan berdasarkan kepentingan sendiri mengambil keputusan di bidang pengaturan (regelendaad) dan di bidang pemerintahan (bestuursdaad). Secara umum, pengertian desentralisasi itu sendiribiasanya dibedakan dalam tiga pengertian, yaitu:

-Desentralisasi dalam arti dekonsentrasi, -Desentralisasi dalam arti pendelegasian kewenangan, -Desentralisasi dalam arti devolusi atau penyerahan fungsi dan kewenangan.

Desentralisasi dalam pengertian dekonsentrasi merupakan pelimpahan beban tugas atau beban kerja dari pemerintah pusat kepada wakil pemerintah pusat di daerah tanpa diikuti oleh pelimpahan kewenangan untuk mengambil keputusan.

Desentralisasi dalam arti pendelegasian kewenangan (transfer of authority) berisi penyerahan kekuasaan untuk mengambil keputusan dari pemerintah pusat kepada pemerintah daerah atau unitorganisasi pemerintahan daerah yang berada di luar jangkauan kendali pemerintah pusat. Desentralisasi dalamarti devolusi merupakan penyerahan fungsi pemerintahan dan kewenangan pusat kepada pemerintahan daerah. Desentralisasi itu sendiri dapat dibedakan dari segi

karakteristiknya, yaitu :

- Desentralisasi teritorial

- Desentralisasi fungsional

- Desentralisasi politik

- Desentralisasi budaya

- Desentralisasi ekonomi

- Desentralisasi administratif 


\section{B. Cabang Kekuasaan Legislatif}

\section{Fungsi Pengaturan (Legislatif)}

Cabang kekuasaan legislatif adalah cabang kekuasaan yang pertama-tama mencerminkan kedaulatan rakyat. Kegiatan bernegara, pertama-tama adalah untuk mengatur kehidupan bersama. Oleh sebab itu, kewenangan untuk menetapkan peraturan itu pertama-tama harus diberikan kepada lembaga perwakilan rakyat atau parlemen atau lembaga legislative. Ada tiga hal penting yang harus diatur oleh para wakil rakyat melalui parlemen, yaitu:

- pengaturan yang dapat mengurangi hak dan kebebasan warga negara,

- peraturan yang dapat membebani harta kekayaan warga negara, dan

- pengaturan mengenai pengeluaran-pengeluaran oleh penyelenggara negara.

Fungsi legislatif juga menyangkut empat bentuk kegiatan, yaitu:

- Prakarsa pembuatan undang-undang

- Pembahasan rancangan undang-undang

- Persetujuan atas pengesahan rancangan undang-undang

- Pemberian persetujuan pengikatan atau ratifikasi atas perjanjian atau persetujuan internasional dan dokumen-dokumen hukum yang mengikat lainnya.

2. Fungsi Pengawasan

Lembaga perwakilan rakyat diberikan kewenangan untuk melakukan kontrol dalam tiga hal itu, yaitu:

1. kontrolatas pemerintahan,

2. kontrol atas pengeluaran, dan

3. kontrol atas pemungutan pajak.

Secara teoritis, fungsi-fungsi control atau pengawasan oleh parlemen sebagai lembaga perwakilan rakyat dapat pula dibedakan, yaitu:

- Pengawasan terhadap penentuan kebijakan

- Pengawasan terhadap pelaksanaan kebijakan

- Pengawasan terhadap penganggaran dan belanja negara

- Pengawasan terhadap pelaksanaan anggaran dan belanja negara

- Pengawasan terhadap kinerja pemerintah

- Pengawasan terhadap pejabat public dalam bentuk persetujuan atau penolakan, atau pun dalam bentuk pemberian pertimbangan oleh DPR.

\section{Fungsi Perwakilan (Representasi)}

Fungsi parlemen sebagai lembaga perwakilan rakyat uang paling pokok sebenaranya adalah fungsi representasi atau perwakilan itu sendiri. Dalam rangka pelembagaan fungsi representasi itu, dikenal pula adanya tiga sistem perwakilan yang dipraktikkan di berbagai negara demokrasi.Ketiga fungsi itu adalah :

- Sistem perwakilan politik, menghasilkan wakil-wakil politik

- Sistem perwakilan teritorial, menghasilkan wakil-wakil daerah

- Sistem perwakilan fungsional menghasilkan wakil wakil golongan fungsional

Dianutnya ketiga sistem perwakilan politik tersebut menentukan bentuk dan struktur pelembagaan sistem perwakilan di setiap negara.

4.Fungsi Deliberatif dan Resolusi Konflik 
Dalam setiap pembuatan aturan, selalu dilakukan pembahasan, baik antar anggota maupun dengan perwakilan pemerintah. Hal yang sama juga terjadi dalam menjalankan fungsi pengawasan dan budgeting yang biasa dimiliki oleh lembaga perwakilan. Perdebatan yang terjadi di dalam parlemen adalah cermin dari perdebatan publik atas suatu masalah. Agar masyarakat terlibat dalam proses perdebatan tersebut, maka diperlukan keterbukaaan par-lemen serta adanya partisipasi masyarakat.

Perdebatan yang terjadi dalam parlemen tujuan utamanya adalah untuk menemukan titik temu atau penyelesaian dari berbagai benturan pandangan dan kepentingan yang berbeda. Titik temu atau penyelesaisan tersebutlah yang nantinya menjadi hukum dan kebijakan yang akan dijalankan. Dengan demikian, perdebatan dalam parlemen dapat dilihat sebagai upaya mengelola konflik guna mendapatkan penyelesaian yang tepat dan dapat diterima semua pihak.

\section{Cabang Kekuasaan Yudisial}

\section{Kedudukan Kekuasaan Kehakiman}

Kekuasaan kehakiman merupakan pilar ketiga dalamsistem kekuasaan negara modern. Dalam bahasa Indonesia,fungsi kekuasaan yang ketiga ini sering kali disebut cabang kekuasaan yudikatif.

\section{Beberapa Prinsip Pokok Kehakiman}

Secara umum dapat dikemukakan ada dua prinsip yang biasa dipandang sangat pokok dalam sistem peradilan, yaitu :

1. the principle of judicial independence,dan

2.the principle of judicial impartiality.

Prinsip independensi itu sendiri antara lain harus diwujudkan dalam sikap para hakim dalam memeriksa dan memutus perkara yang dihadapinya. Di sarnping itu,independensi juga tercermin dalam berbagai pengaturan mengenai hal-hal yang berkaitan dengan pengangkatan,masa kerja, pengembangan karier, sistem penggajian, dan pemberhentian para hakim. Sementara itu, prinsip kedua yang sangat penting adalah prinsip ketidak berpihakan Dalam praktik,ketidak berpihakan atau impartiality itu sendiri mengandung makna dibutuhkan-nya hakim yang tidak saja bekerja secara imparsial (to be impartial), tetapi juga terlihat bekerja secara imparsial Dalam The Bangalore Principles itu, tercantum adanya enam prinsip penting yang harus dijadikan pegangan bagi para hakim di dunia, yaitu prinsip-prinsip independence, impartiality, integrity, propriety, equality, dan competence and diligence. Mahkamah Konstitusi telah menetapkan Kode EtikHakim Konstitusi sebagaimana tertuang dalam PeraturanMahkamah Konstitusi No. 07/PMK/2005.

\section{Struktur Organisasi Kehakiman}

Dalam struktur organisasi kekuasaan kehakiman,terdapat beberapa fungsi yang di lembagakan secara internal dan eksternal. Terkait dengan jabatan-iabatan kehakiman itu, terdapat pula pejabatpejabat hukum yaitu: 1 . pejabat penyidik, 2. pejabat penuntut umum, dan 3. advokat yang juga diakui sebagai penegak hukum.

Di lingkungan pejabat penyidik, terdapat : 1.polisi, 2. Jaksa, 3. penyidik Komisi Pemberantasan Korupsi (KPK), dan 4. penyidik pegawai negeri sipil.

Mereka yang menjalankan fungsi penuntutan adalah: 1. jaksa penuntut umum, dan 2. Komisi Pemberantasan Korupsi (KPK).

Sementara itu, dalam lingkungan internal organisasi pengadilan, dibedakan dengan tegas adanya tiga jabatan fungsional, yaitu: 1. Hakim, 2. Panitera, dan 3. pegawai administrasi lainnya. 


\section{Cabang Kekuasaan Eksekutif}

\section{Sistem Pemerintahan}

Cabang kekuasaan eksekutif adalah cabang kekuasaan yang niemegang kewenangan administrasi pemerintahan negara yang tertinggi. Dalam hubungan ini, di dunia dikenal adanya tiga sistem pemerintahan negara yaitu :

- sistem pemerintahan presidentil,

- sistem pemerintahan parlementer atau sistem kabinet; dan

- sistem campuran.

Sistem pemerintahan itu dikatakan bersifat parlementer apabila

- sistem kepemimpinannya terbagi dalam jabatan kepala negara dan kepala pemerintahan sebagai dua jabatan yang terpisah.

- jika sistem pemerintahannya di tentukan harus bertanggung jawab kepada parlemen sehingga dengan demikian,

- kabinet dapat dibubarkan apabila tidak mendapat dukungan parlemen, dan sebaliknya

- parlemen juga dapat dibubarkan oleh Kepala Negara apabila dianggap tidak dapat memberikan dukungan kepada pemerintah

\section{Kementerian Negara}

Dalam sistem pemerintahan kabinet atau parlementer, Menteri tunduk dan bertanggung jawab kepada parlemen. Sedangkan dalam sistem presidentil, para menteri tunduk dan bertanggung jawab kepada Presiden. Dalam sistem parlementer jelas sekali bahwa kedu-dukan menteri adalah bersifat sentral. Kinerja pemerintahan sepenuhnva berada ditangan para menteri yang dipimpin oleh seorang Perdana Menteri itu. Karena sangat kuatnya kedudukan para menteri,parlernen pun dapat dibubarkan oleh mereka.

Sebaliknya ,kabinet Juga dapat dibubarkan oleh parlemen apabila mendapat mosi tidak percaya dari parle-men. Demikianlah perimbangan kekuatan di antara kabinet dan parlemen dalam sistem pemerintahan parlementer. Dalam sistem presidentil, yang bertanggung jawab adalah Presiden, bukan Menteri sehingga sudah seharusnya nuansa pekerjaan para menteri dalam sistem presidentil itu bersifat lebih profesional dari pada politis.

Oleh sebab itu, untuk diangkat menjadi menteri seharus nya seseorang benar-benar memiliki kualifikasi teknis dan profesio-nal untuk memimpin pelaksanaan tugas-tugas pemerintahan berdasarkan prinsip meritokrasi. 